\title{
QUALITATIVE PHYTOCHEMICAL SCREENING AND ANTIOXIDANT ACTIVITY OF ELYTRARIA ACAULIS LINDAU (ACANTHACEAE)
}

\author{
MANIGANDAN M*, KOLANJINATHAN K \\ Department of Microbiology, Faculty of Science, Annamalai University, Chidambaram, Tamil Nadu, India. \\ Email: senthilmanigandan@gmail.com
}

Received: 19 October 2016, Revised and Accepted: 26 October 2016

\section{ABSTRACT}

Objectives: To analyze the phytochemicals quantitatively and screening the antioxidant efficacy of methanol extracts of Elytraria acaulis plant extract by in vitro.

Methods: The total phenols, flavonoids, and tannin contents analyzed by Folin-Ciocalteu method, aluminum chloride colorimetric and calculated as gallic acid equivalents/g (GAE/g) of dry weight. Free radical scavenging activity was screened using 1,1-diphenyl-2-picrylhydrazyl (DPPH), radical scavenging activities, and ferric reducing power assay was also analyzed.

Results: The total phenolic content of the aqueous leaf extract was $46.84 \mu \mathrm{g}$ GAE/g of extract powder. Significantly similar levels of total flavonoid and tannin contents of the plant were 41.72 and $39.50 \mu \mathrm{g} \mathrm{GAE} / \mathrm{g}$, respectively. The plant extracts showed appreciable free radical scavenging activities at the highest concentration of $400 \mu \mathrm{g} / \mathrm{mL}$ superoxide anion radical with $\mathrm{IC}_{50}$ values $(107.7 \pm 1.081 \mu \mathrm{g} / \mathrm{mL})$, and for DPPH and considerably high amount of radical scavenging activity was found with very low $\mathrm{IC}_{50}$ values $(4.3 \pm 0.88 \mu \mathrm{g} / \mathrm{mL})$ compared with quercetin.

Conclusion: The phenolic and flavonoid compounds provide substantial antioxidant properties which could be effectively used for pharmaceutical, nutraceutical as well as anti-inflammatory applications.

Keywords: Phenols, Flavonoids, 1,1-diphenyl-2-picrylhydrazyl, Pharmaceuticals.

(C) 2017 The Authors. Published by Innovare Academic Sciences Pvt Ltd. This is an open access article under the CC BY license (http://creativecommons. org/licenses/by/4. 0/) DOI: http://dx.doi.org/10.22159/ajpcr.2017.v10i2.15759

\section{INTRODUCTION}

In search of novel sources of antioxidants from the last decades, medicinal plants have been extensively studied for their antioxidant activity. From ancient times, herbs have been used in many areas, including nutrition, medicine, flavoring, beverages, cosmetics, etc. The plants are a rich source of large amount of drugs comprising to different groups such as antispasmodics, emetics, anti-cancer, and antimicrobials. A large number of the plants are claimed to possess the antibiotic properties in the traditional system and are also used extensively by the tribal people worldwide. It is now believed that nature has given the cure of every disease in one way or another. Plants have been known to relieve various diseases in Ayurveda. Therefore, the researchers today are emphasizing on evaluation and characterization of various plants and plant constituents against a number of diseases based on their traditional claims of the plants given in Ayurveda [1]

Extraction is an intimate process to isolate the components from plant cells, which may contain a complex mixture of many metabolites, such as alkaloids, glycosides, terpenoids, flavonoids, lignan, phenols, and saponins most of the researchers prefers hot continuous extraction (soxhlet extraction). The advantage of this system is that instead of many portions of warm solvent being passed through the sample, just one batch of solvent is recycled $[2,3]$

Oxidation is an essentially biological process for energy production in many living organisms. However, excessive reactive oxygen species, produced in vivo during some oxidative reactions, are not only strongly associated with lipid peroxidation but also involved in the development of some chronic diseases, such as cancer, cardiovascular disease, atherosclerosis, and diabetes [4]. The aim of the present study is to screen the antioxidant and phytochemical properties of Elytraria acaulis plant extracts.

\section{METHODS}

\section{Collection of plant}

The Indigenous plant variety E. acaulis from the Family of Acanthaceae was collected from the places in and around Bhuvanagiri, Cuddalore district and identified morphologically and taxonomically; the specimens were submitted to the Department of Botany, Annamalai University.

\section{Preparation of plant extract}

The collected plant material was washed cleanly in tap water and then air dried under shadow condition at room temperature $\left(25^{\circ} \mathrm{C}\right)$ for 2-3 weeks until it becomes brittle. After complete drying, the plant material was grinded to a fine powder using an electrical blender. $50 \mathrm{~g}$ of dried powder was packed in the soxhlet apparatus with $300 \mathrm{~mL}$ of solvents (methanol, acetone, chloroform, and hexane) extracted until the extract was clear. The solvents from the extracts were evaporated using rotary vacuum evaporator, and the extract was stored in a refrigerator for further use [5].

\section{Determination of total phenol}

The total phenolic content of the methanol extract of E. acaulis plant was determined by using the Folin-Ciocalteu reagent according to the method of Singleton et al. [6]. About $1 \mathrm{~mL}$ of plant extract was mixed with $5 \mathrm{~mL}$ of Folin-Ciocalteu reagent at the ratio of 1:10, followed by the addition of $4 \mathrm{~mL}$ of $\mathrm{Na}_{2} \mathrm{CO}_{3}(0.7 \mathrm{M})$. Subsequently, the mixture was shaken for $2 \mathrm{hrs}$ at room temperature and the absorbance was measured at $760 \mathrm{~nm}$. All the tests were performed at triplicates. The concentration of total phenolic compounds was determined as $\mu$ g gallic acid equivalents using the following equation obtained from a standard gallic acid graph:

Absorbance $=0.001 \times$ pyrocatechol $(\mu \mathrm{g})+0.0033$. 


\section{Total flavonoid content}

The total flavonoid content of the crude extract was determined by the aluminum chloride colorimetric method [7]. In brief, crude extract $1 \mathrm{mg} / \mathrm{mL}$ ethanol were made up to $1 \mathrm{~mL}$ with methanol, mixed with $4 \mathrm{~mL}$ of distilled water and then $0.3 \mathrm{~mL}$ of $5 \% \mathrm{NaNO}_{2}$ solution; $0.3 \mathrm{~mL}$ of $10 \% \mathrm{AlCl}_{3}$ solution was added after 5 minutes of incubation, and the mixture was allowed to stand for 6 minutes. Then, $2 \mathrm{~mL}$ of $1 \mathrm{~mol} / \mathrm{L}$ $\mathrm{NaOH}$ solution were added, and the final volume of the mixture was brought to $10 \mathrm{~mL}$ with double-distilled water. The mixture was allowed to stand for 15 minutes, and absorbance was measured at $510 \mathrm{~nm}$. The total flavonoid content was calculated from a calibration curve, and the result was expressed as mg rutin equivalent per g dry weight.

\section{Estimation of total tannins}

Tannins content of $E$. acaulis was estimated following the method of Siddhuraj and Manian [8]. $500 \mu \mathrm{L}$ of the extracts were taken in test tubes and treated with $100 \mathrm{mg}$ of polyvinylpolypyrrolidone and $500 \mu \mathrm{L}$ of distilled water. This solution was incubated at $4^{\circ} \mathrm{C}$ for $4 \mathrm{hrs}$. Then the sample was centrifuged at $5000 \mathrm{rpm}$ for 5 minutes, and $20 \mu \mathrm{L}$ of the supernatant was taken. This supernatant has only simple phenolics free of tannins - the tannins would have been precipitated along with the polyvinylpolypyrrolidone. The phenolics content of the supernatant was measured at $725 \mathrm{~nm}$ and expressed as the content of free phenolics on a dry matter basis. From the above results, the tannins content of the extract was calculated as follows:

$$
\begin{aligned}
& \operatorname{Tannin}\left(\mathrm{mg} \frac{\mathrm{GAE}}{\mathrm{g}} \text { extract }\right)=\text { Total phenolics }\left(\mathrm{mg} \frac{\mathrm{GAE}}{\mathrm{g}} \text { extract }\right) \\
& \text {-freephenolics(mgGAE / gextract) }
\end{aligned}
$$

\section{1,1-diphenyl-2-picrylhydrazyl (DPPH) scavenging activity}

The free radical scavenging activity of extracts was determined using the DPPH method [9]. Different concentrations of extracts and positive control in methanol solution $(100 \mu \mathrm{L})$ were added to $4 \mathrm{~mL}$ of DPPH methanol solution $(0.1 \mathrm{mM})$. An equal amount of methanol was used as a blank. After incubation at room temperature for 30 minutes in the dark, the absorbance was measured at $517 \mathrm{~nm}$ using a UV spectrophotometer. The activity of scavenging (\%) was calculated using the following formula:

$\mathrm{DPPH}$ radical scavenging $(\%)=[(\mathrm{OD}$ control-OD sample $) / O D$ control] $\times 100 \%$

\section{Superoxide scavenging activity}

The superoxide anion radical scavenging activity of methanol extracts was performed according to NTB reduction method [10]. The reaction was initiated by adding $100 \mu \mathrm{L}$ of phenazine methosulfate solution $(60 \mu \mathrm{M}, \mathrm{PMS})$ in phosphate buffer ( $\mathrm{pH} 7.4)$ to the reaction mixture followed by incubation at $25^{\circ} \mathrm{C}$ for 5 minutes and the absorbance at $560 \mathrm{~mm}$ was measured against blank.

Ascorbic acid was used as the standard.

Superoxide scavenging activity $(\%)=\frac{\operatorname{Abs}(\text { control })-\operatorname{Abs}(\text { sample })}{\mathrm{Abs}(\text { control })} \times 100$

Where, Abs (control): Absorbance of the control and Abs (test): Absorbance of the extracts/standard.

\section{Determination of ferric reducing power assay (FRAP)}

The reducing power was performed according to the method of Oyaizu [11], ferric-tripyridyl-triazine (TPTZ-Fe3+) complex is reduced to TPTZ-Fe2 + in the presence of antioxidants. Various concentrations of samples $(25-200 \mu \mathrm{g} / \mathrm{mL})$ in $200 \mu \mathrm{L}$ of methanol were mixed with $0.5 \mathrm{~mL}$ phosphate buffer (0.2 M, pH 6.6) and $0.5 \mathrm{~mL}$ potassium ferricyanide $(1 \% \mathrm{w} / \mathrm{v})$. The mixture was incubated at $50^{\circ} \mathrm{C}$ for 20 minutes. After terminating the reaction by adding trichloroacetic acid $(10 \% \mathrm{w} / \mathrm{v})$, the mixture was centrifuged at $1000 \times g$ for 10 minutes. The supernatant of solution $0.5 \mathrm{~mL}$ was mixed with $0.5 \mathrm{~mL}$ distilled water and $0.1 \mathrm{~mL}$ $\mathrm{FeCl}_{3}(0.1 \% \mathrm{w} / \mathrm{v})$. After 5 minutes, the absorbance was measured at $700 \mathrm{~nm}$ in a microplate reader. Ascorbic acid is used as a positive control. FRAP value is expressed as the number of equivalence of gallic acid.

\section{RESULTS}

\section{Quantitative analysis of phytochemical compounds}

The phytochemical analysis of the plant extract showed the presence of various biologically active chemical compounds such as alkaloids, amino acids, catachols, flavonoids, phenols, saponins, steroids, and tannins and the results were presented in Table 1 . The amount of phytochemical compounds present in the E. acaulis extract was quantitatively determined by standard procedures. All the extracts of E. acaulis showed different amount of phytochemicals. The total phenolic content was high in the methanol extract of E. acaulis.

\section{DPPH scavenging activity}

The DPPH radical scavenging activity of methanol extracts of EAM at five different concentrations $(3.125,6.25,12.5,25$, and $50 \mu \mathrm{g} /$ $\mathrm{mL}$ ) was tested, and the results were shown in Fig. 1 . All the extracts exhibited a dose-dependent increase in activity. The highest DPPH scavenging activity was shown E. acaulis Lind extracts $(93.06 \%$ and $92.47 \%$ for precipitate and liquid fractions respectively) at $50 \mu \mathrm{g} / \mathrm{mL}$ concentration. The $\mathrm{IC}_{50}$ value of the E. acaulis extract $(4.3 \mu \mathrm{g} / \mathrm{mL})$ was comparable to that of ascorbic acid standard $(3.2 \mu \mathrm{g} / \mathrm{mL})$.

\section{Superoxide scavenging activity}

Methanol extract of E. acaulis was found to scavenge the superoxide radicals generated by riboflavin photoreduction method. The highest superoxide anion scavenging potential as indicated by the lowest $\mathrm{IC}_{50}$ concentration was $\mathrm{IC}_{50}-107.7 \mu \mathrm{g} / \mathrm{mL}$. This sample compares well with the ascorbic acid standard of $\mathrm{IC}_{50} 91.2 \mu \mathrm{g} / \mathrm{mL}$.

\section{FRAP}

The reducing power of different methanol extracts of E. acaulis which may serve as a significant reflection of the antioxidant activity was evaluated using potassium ferricyanide reduction method, and the results were noted in Fig. 2. All the studied extracts exhibited considerable reducing ability when compared with the standard BHT and the results were documented in the Fig. 2.

The absorbance value and concentration of extracts showed linear relationship. Therefore, increasing OD values indicate increasing trend in reducing power.

Table 1: Qualitative phytochemical screening of $E$. acaulis

\begin{tabular}{lll}
\hline S. No. & $\begin{array}{l}\text { Phytochemical compounds } \\
\text { in methanol extract }\end{array}$ & $\begin{array}{l}\text { Quantitative } \\
\text { analysis } \boldsymbol{\mu g} / \mathbf{m g}\end{array}$ \\
\hline 1 & Total flavonoids & 41.72 \\
2 & Total phenolic & 46.84 \\
3 & Tannins & 39.50 \\
\hline
\end{tabular}

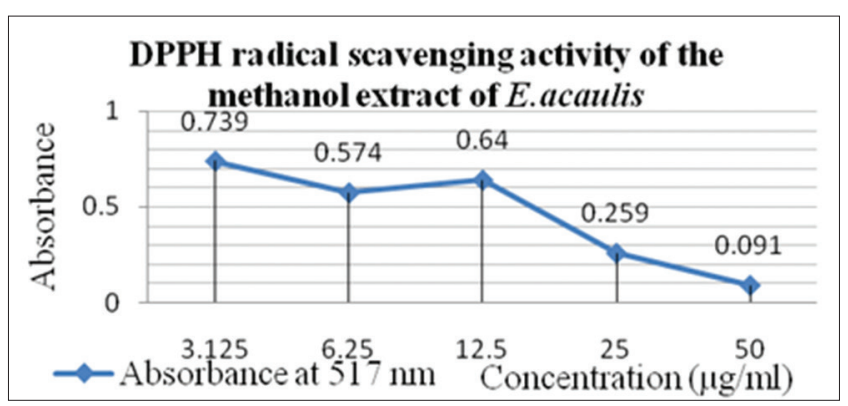

Fig. 1: 1,1-diphenyl-2-picrylhydrazyl radical scavenging activity of methanol extract 
Table 2: Superoxide anion scavenging activity

\begin{tabular}{lllll}
\hline Sample & Concentration $(\boldsymbol{\mu g} / \mathbf{m L})$ & Absorbance at $\mathbf{5 6 0} \mathbf{~ n m}$ & \% inhibition & IC \\
\hline Control & $(\boldsymbol{\mu g} / \mathbf{m L})$ \\
E. acaulis extract & 25 & 1.125 & & \\
& 50 & $0.629 \pm 0.001$ & $39.35 \pm 0.137$ & $107.7 \pm 1.081$ \\
& 100 & $0.567 \pm 0.014$ & $52.62 \pm 2.760$ & \\
& 200 & $0.457 \pm 0.030$ & $59.57 \pm 1.159$ & \\
& 400 & $0.326 \pm 0.005$ & $71.02 \pm 0.051$ & \\
\hline
\end{tabular}

Values shown are mean \pm SEM for four tests. $\mathrm{p}<0.001$, as compared to control. SEM: Standard error of mean

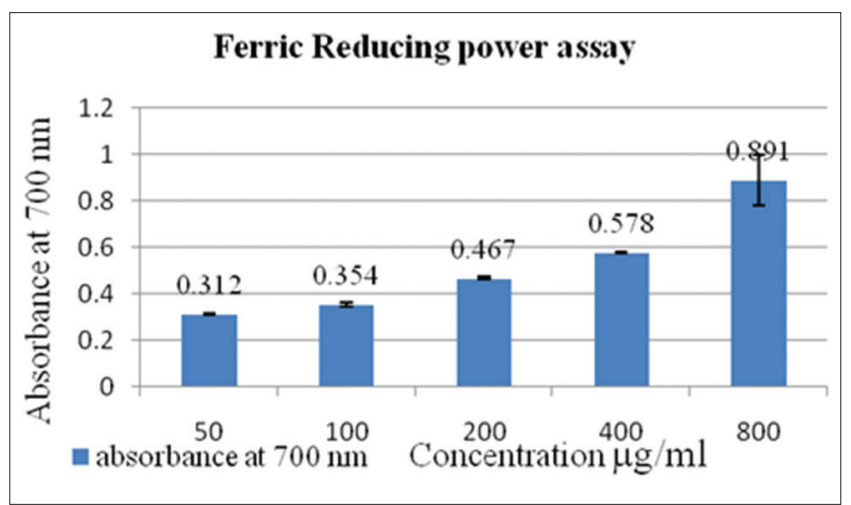

Fig. 2: Ferric reducing power assay

\section{DISCUSSION}

The antiradical activity of the methanol extract was measured by the ability to scavenge DPPH free radicals with higher scavenging activity at various concentrations ranging from $3.125 \mu \mathrm{g} / \mathrm{mL}$ to $50 \mu \mathrm{g} / \mathrm{mL}$. This result proved that the extracts are capable of donating an electron or hydrogen which could react with DPPH radical and the $\mathrm{IC}_{50}$ value of E. acaulis extract ( $4.3 \mu \mathrm{g} / \mathrm{mL}$ ) was comparable to that of ascorbic acid standard $(3.2 \mu \mathrm{g} / \mathrm{mL})$. FRAP absorbance value and concentration of extracts showed linear relationship. Therefore, increasing OD values indicate increasing trend in reducing power.

The availability of phenolic compounds such as total phenols, tannins, and flavonoids in high range consists of medicinal values including anticancer [12,13], antioxidant [14,15], antimicrobial $[15,16]$, woundhealing [17], and anti-inflammatory [18], which in turn helps for improvement of novel drugs from our present investigation.

Phenolic compounds consist of redox properties which induce them to act as antioxidants; their hydroxyl groups facilitate their free radical scavenging ability, and the total phenolic concentration could be used as base for rapid screening of antioxidant activity [19].

Superoxide is a reactive oxygen species, damage cells, and DNA, leading to various diseases in human [20]. Superoxide scavenging activity, determined by the nitroblue tetrazolium assay, was $62.16 \%$ for $500 \mathrm{~g} / \mathrm{mL}$ of the root extract and $89.36 \%$ for ascorbic acid. In methanolic root extract of $E$. acaulis a high free radical scavenging activity of $79.38 \%, 82.92 \%$, and $83.5 \%$ in relation to concentrations of 200,300 , and $400 \mu \mathrm{g} / \mathrm{mL}$, respectively [21].

Plants rich in flavonoids and phenolics are good source of natural antioxidant and antibacterial activities. Qualitative and quantitative analysis of major individual phenolics in these leaves explains the relationships between total antioxidant capacity and total phenolic contents in these plants [22]. The presence of phenolic content in plants strongly reveals the antioxidant activity [23].

\section{CONCLUSION}

The antioxidant properties of phenols, flavonoids, and tannin content of $E$. acaulis plant extracts showed maximum free radical scavenging activities. This result is, in turn, posing new ways of natural sources of antioxidant and phytochemical compounds and explains the relationships between the total antioxidant and total phenolics of the plants.

\section{REFERENCES}

1. Tiwari P, Kumar B, Kaur M, Kaur G, Kaur H. Phytochemical screening and Extraction: A Review. Int Pharm Sci 2011;1(1):98-106.

2. Handa SS, Khanuja SP, Longo G, Rakesh DD. Extraction technologies for medicinal and aromatic plants. Int Cent Sci High Tech Trieste 2008:2:21-5

3. Nikhal SB, Dambe PA, Ghongade DB, Goupale DC. Hydroalcoholic extraction of Mangifera indica (leaves) by soxhletion. Int J Pharm Sci 2010;2(1):30-2.

4. Moskovitz J, Yim MB, Chock PB. Free radicals and disease. Arch Biochem Biophys 2002;397(2):354-9.

5. Chessbrough M. Medical Laboratory Manual for Tropical Countries. Linacre House, Oxford: Jordan Hill; 2000. p. 260.

6. Singleton V, Orthofer R, Lamuela-Ravento R. Analysis of total phenols and other oxidation substrates and antioxidants by means of FolinCiocalteu reagent. In: Packer L, editor. Oxidants and Antioxidants, Part A. Methods in Enzymology. Vol. 299. San Diego: Academic Press; 1999. p. $152-78$,

7. Chang C, Yang M, Wen H, Chern J. Estimation of total flavonoid content in propolis by two complementary colorimetric methods. J Food Drug Anal 2002;10(3):178-82.

8. Siddhuraju P, Manian S. The antioxidant activity and free radical scavenging capacity of dietary phenolic extracts from horse gram (Macrotyloma uniflorum (Lam.) Verdc.) Seeds. Food Chem 2007;105(3):950-8.

9. Saha K, Lajis NH, Israf DA, Hamzah AS, Khozirah S, Khamis S, et al. Evaluation of antioxidant and nitric oxide inhibitory activities of selected Malaysian medicinal plants. J Ethnopharmacol 2004;92(2-3):263-7.

10. Nishikimi M, Appaji N, Yagi K. The occurrence of superoxide anion in the reaction of reduced phenazine methosulfate and molecular oxygen. Biochem Biophys Res Commun 1972;46(2):849-54.

11. Oyaizu M. Studies on products of browning reaction. Antioxidative activities of products of browning reaction prepared from glucosamine. Jpn J Nutr 1986;44(6):307-15.

12. Lin Y, Shi R, Wang X, Shen HM. Luteolin, a flavonoid with potential for cancer prevention and therapy. Curr Cancer Drug Targets 2008;8(7):634-46.

13. Khacha-ananda S, Tragoolpua K, Chantawannakul P, Tragoolpua Y. Antioxidant and anti-cancer cell proliferation activity of propolis extracts from two extraction methods. Asian Pac J Cancer Prev 2013;14(11):6991-5.

14. Pourmorad F, Hosseinimehr SJ, Shahabimajd N. Antioxidant activity, phenol and flavonoid contents of some selected Iranian medicinal plants. Afr J Biotechnol 2006;5(11):1142-5.

15. Sengul M, Yildiz H, Gungor N, Cetin B, Eser Z, Ercisli S. Total phenolic content, antioxidant and antimicrobial activities of some medicinal plants. Pak J Pharm Sci 2009;22(1):102-6.

16. Hendra R, Ahmad S, Sukari A, Shukor MY, Oskoueian E. Flavonoid analyses and antimicrobial activity of various parts of Phaleria macrocarpa (Scheff.) Boerl fruit. Int J Mol Sci 2011;12(6):3422-31.

17. Nayak BS, Pinto Pereira LM. Catharanthus roseus flower extract has wound-healing activity in Sprague Dawley rats. BMC Complement Altern Med 2006;6:41

18. Rathee P, Chaudhary H, Rathee S, Rathee D, Kumar V, Kohli K. Mechanism of action of flavonoids as anti-inflammatory agents: A review. Inflamm Allergy Drug Targets 2009;8(3):229-35.

19. Soobrattee MA, Neergheen VS, Luximon-Ramma A, Aruoma OI, 
Bahorun OT. Phenolics as potential antioxidant therapeutic agents: Mechanism and actions. Mutat Res Fundam Mol 2005;579(1-2):200-13.

20. Shukla S, Mehta A, Bajpai VK, Shukla S. In vitro antioxidant activity and total phenolic content of ethanolic leaf extract of Stevia rebaudiana Bert. Food Chem Toxicol 2009;47(9):2338-43.

21. Jagadeesan K, George T, Kamalanathan MN, Ilayaraja T. Studies on the anthelmintic and antioxidant activity of root extracts of E. acaulis. Adv
Anim Vet Sci 2014;2(8):457-63

22. Saiah H, Allem R, El Kebir FZ. Antioxidant and antibacterial activities of six Algerian medicinal plants. Int J Pharm Pharm Sci 2015;8(1):367-74

23. Chandrika M, Chellaram C. Efficacy of antioxidation and antiinflammation of the leaf extracts of Borreria hispida. Int J Pharm Pharm Sci 2016;8(8):369-72. 